\title{
Analysis of Doppler Reactivity Coefficient on the Typical PWR-1000 Reactor with Mox Fuel
}

\section{Rokhmadi, Suwoto, Zuhair}

Center for Nuclear Reactor Technology and Safety (PTKRN) - BATAN, PUSPIPTEK Area, Building No. 80, Serpong, Tangerang Selatan, 15310

\section{Abstract}

Doppler coefficient is defined as a relation between fuel temperature changes and reactivity changes in the nuclear reactor core. Doppler reactivity coefficient needs to be known because of its relation to the safety of reactor operation. This study is intended to determine the safety level of the typical PWR-1000 core by calculating the Doppler reactivity coefficient in the core with $\mathrm{UO}_{2}$ and MOX fuels. The typical PWR-1000 core is similar to the PWR AP1000 core designed by Westinghouse but without Integrated Fuel Burnable Absorber (IFBA) and Pyrex. Inside the core, there are $\mathrm{UO}_{2}$ fuel elements with $3.40 \%$ and $4.45 \%$ enrichment, and MOX fuel elements with $0.2 \%$ enrichment. By its own way, the presence of Plutonium in the MOX fuel will contribute to the change in core reactivity. The calculation was conducted

Corresponding Author: Rokhmadi, email: rokh_rsg@batan.go.id

Received: 29 July 2016 Accepted: 21 August 2016 Published: 21 September 2016

\section{Publishing services} provided by Knowledge E

(c) Rokhmadi. et al. This article is distributed under the terms of the Creative Commons Attribution License, which permits unrestricted use and redistribution provided that the original author and source are credited.

Selection and Peer-review under the responsibility of the ICONETS Conference Committee.

\section{G OPEN ACCESS} using MCNPX code with the ENDF/B- VII nuclear data. The reactivity change was investigated at various temperatures. The calculation results show that the core reactivity coefficient of both $\mathrm{UO}_{2}$ and MOX fuel are negative, so that the reactor is operated safely.

Keywords: Typical PWR-1000 core, MOX, Doppler reactivity coefficient, MCNPX, ENDF/B-VII

\section{Introduction}

Mixed oxide fuel, composing $\mathrm{MOX}, \mathrm{PUO}_{2}$ and $\mathrm{UO}_{2}[1]$, is a mixture of plutonium and natural uranium or depleted uranium, which is almost similar with the enrichment of uranium used in the most of nuclear reactors. MOX fuel can be an alternative uranium fuel with low enrichment in light water reactors (LWRs). Most commercial nuclear power plants (NPPs) are of LWR type. In NPPs, about $10 \%$ of the used fuel are produced and can be used as a large number of MOX source in the world [2]. During operation, an increase in fuel temperature will cause a decrease in thermal conductivity of the fuel pellets [3-5], causing a slow down of heat flow due to fission reactions. That will result in change of absorption cross section of $\mathrm{U}-233, \mathrm{U}-235$ and $\mathrm{Pu}-239$, so that at the end the reactivity will change following the temperature change. Due to the smaller thermal conductivity of MOX fuel than the $\mathrm{UO}_{2}$ fuel, a same temperature change will result in a different Doppler reactivity coefficient among those fuels.

Fuel temperature reactivity coefficient, or better known as the Doppler reactivity coefficient, is an important parameter and a dominant factor to achieve the safe operation of the reactor by controlling the reactivity transients. The Doppler reactivity coefficient 
is part of the coefficient reactivity feedback, together with the moderator temperature and density coefficient, which are designed to be negative for reactor control purpose. When the fuel or moderator temperature increase due to the increase in reactor power, the negative feedback will decrease the reactivity automatically, so that the reactor is still in safe condition. This characteristic is known as the reactor inherent safety.

The Doppler effect and the isotope $\mathrm{U}-238$ ensure the negative reactivity coefficient at the beginning of the cycle (BOC) of the reactor. However, the accumulation of P-239 due to the burn up can lead to the positive reactivity or an increase in the Doppler reactivity. The existence of plutonium in the MOX fuel needs a special attention because of the shifting towards a broader spectrum of the core and the possibility of the positive reactivity coefficient [6]. The Doppler reactivity coefficient is defined as fractional change in reactivity caused by changes in fuel temperature. This coefficient is considered more important than the moderator reactivity coefficient because an increased fuel temperature is followed immediately by an increase in reactor power. The main effect is due to the Doppler reactivity resonance capture of $\mathrm{U}-238$ fission and absorption ratio changes due to changes in fuel temperature $[7,8]$.

This paper presents the effect of the MOX fuel in a typical PWR-1000. The typical PWR1000 is a pressurized water reactor (PWR) reactor type similar to the AP-1000 without the use of 104 Integrated Fuel Burnable Absorber (IFBA) and pyrex. The purpose of the research is to determine the effect of MOX fuel to the Doppler reactivity coefficient of the typical PWR-1000 reactor core. The research was performed using the Monte Carlo MCNPX transport program [9] to calculate the MOX fuel assemblies in the typical PWR-1000 reactor core. During that process, a Nuclear Data Library continuous energy dependent temperature of ENDF/B-VII [10] files was generated using NJOYgg code for the whole calculation. The results of the MOX fuel has been compared with the calculation of a standard $\mathrm{UO}_{2}$ fuel also loaded in the typical PWR-1000.

\section{Description of the Typical PWR-1000 Reactor}

The PWR-1000 typical reactor core is designed to produce power output of 1000 MWe or 3400 MWth from the $157 \mathrm{UO}_{2}$ fuel assemblies. Each fuel assembly is arranged by $17 \times 17$ elements, consisting of 264 fuels rod and 25 guide tubes. The number of control rod assemblies in the core are 69 pieces consisting of 53 pieces of rod cluster control assembly (RCCA) and 16 pieces of gray rod control assembly (GRCA) [11]. Table 1 shows the design parameters and the description of the reactor core.

The core as shown in Figure 1 is surrounded by a single row of reflector assemblies of the same width as the fuel assembly containing $2.50 \mathrm{~cm}$ thick baffle (Fe-Cr-Ni-Mn). The outer radial boundary condition is vacuum. Each fuel assembly consists of $17 \times 17$ square pin cell lattice as shown in Figure 2. The pin cell pitch equals to 1.26 corresponding to an assembly width of $21.42 \mathrm{~cm}$, which is located at the highest worth regions in the vicinity of the guide tube. Their purpose is to compensate excess reactivity of the fresh fuel.

\section{Methodology}

\section{Design of the MOX core :}

The MOX core of the typical PWR-1000 is designed from the original $\mathrm{UO}_{2}$ core of AP 1000 [12] by replacing the $\mathrm{UO}_{2}$ fuel with $2.35 \%$ enrichment with the MOX fuel, as shown in Figure 3. 
TABLE 1: Desain parameters of typical PWR-1000 reactor [12].

\begin{tabular}{|c|c|}
\hline Parameter & Value \\
\hline \multicolumn{2}{|l|}{ Power of reactor: } \\
\hline Thermal power, MWth & 3400 \\
\hline Electric power, MWe & 1117 \\
\hline \multicolumn{2}{|l|}{ Active core: } \\
\hline High of fuel achtive on first core, $\mathrm{cm}$ & 426,7 \\
\hline Equivalen diameter, cm & 304 \\
\hline \multicolumn{2}{|l|}{ Fuel assembly (FA): } \\
\hline arrangement one perangkat & $17 \times 17$ \\
\hline Number of FA on core & 157 \\
\hline Fuel material & $\mathrm{UO}_{2}$ (sintered) \\
\hline Enrichment of ${ }^{235} \mathrm{U}, \mathrm{w} \%$ & 2,$35 ; 3,40$ dan 4,45 \\
\hline Enrichment of MOX, w\% & 2 \\
\hline Number of fuel rod & 264 \\
\hline Number of guide tube/instrument guide thimbles & $24 / 1$ \\
\hline \multicolumn{2}{|l|}{ Structure of core: } \\
\hline Material of core barrel & $\mathrm{SS} 304$ \\
\hline Diameter of core barrel, ID/OD, cm & $339,72 / 349,88$ \\
\hline Material of baffle & $\mathrm{SS}_{304}$ \\
\hline Thickness of baffle, $\mathrm{cm}$ & 2,2 \\
\hline \multicolumn{2}{|l|}{ Fuel $\mathrm{UO}_{2}$ : } \\
\hline $\operatorname{rod}($ pitch), cm & 0,81915 \\
\hline Pelet diameter,cm & 0,01645 \\
\hline Gap thickness,cm & 0,0572 \\
\hline Clading material & Zirlo \\
\hline Guide tube: & $1,123 / 1,224$ \\
\hline Inner/outer diameter, cm & ZIRLO \\
\hline Tube material & 1,260 \\
\hline
\end{tabular}

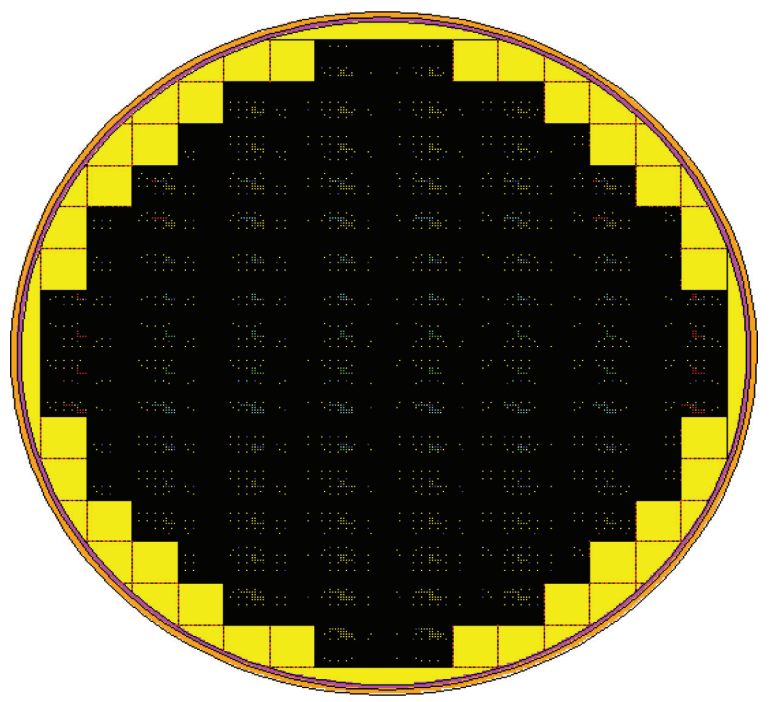

Figure 1: Typical of PWR-1000 core using VISED code. 


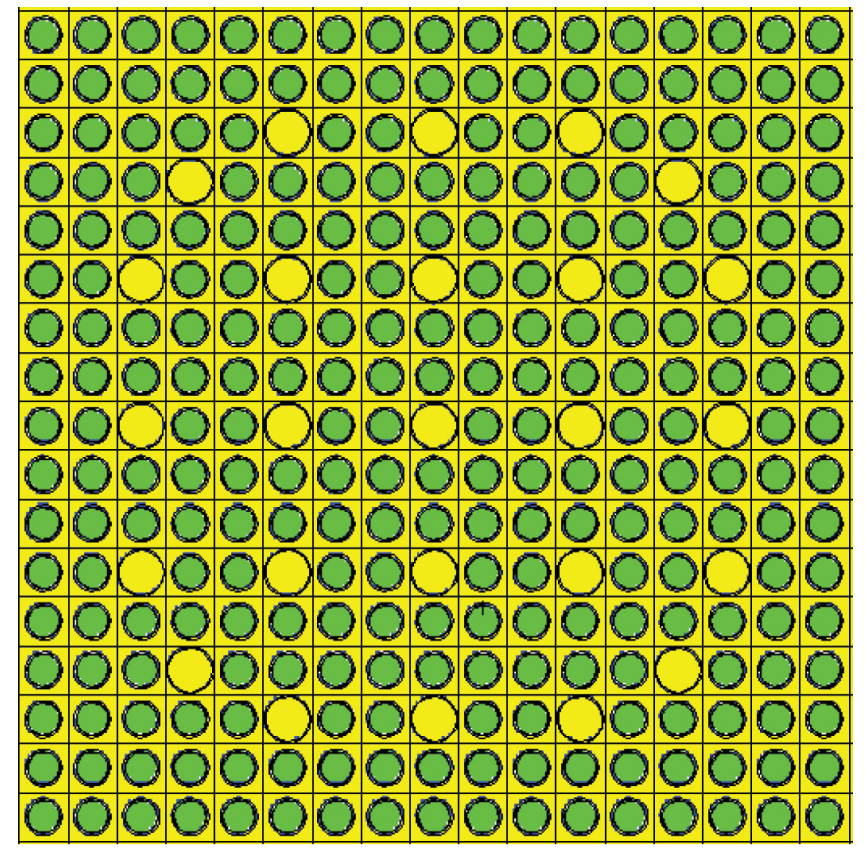

D Fuel

O Guide tube

Figure 2: Fuel assembly cross section of typical PWR-1000 core (green: fuel element, yellow: guide tube).

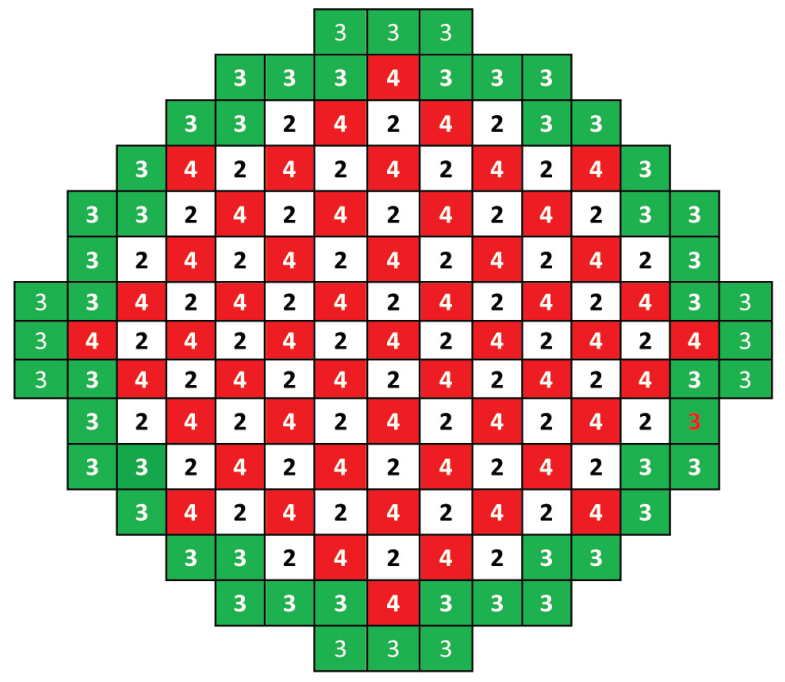

$\begin{array}{llllll}4 & \text { MOX: }: 2.0 \% & 2 & \mathrm{UO}_{2}: 3.40 \% & 3 & \mathrm{UO}_{2}: 4.45 \%\end{array}$

Figure 3: Design of the MOX core in the typical PWR-1000.

Based on Figure 3, the number of fuel assemblies with different fuel type and enrichment are listed in Table 2.

TABLE 2: Number of fuel assemblies in the MOX core.

\begin{tabular}{|c|c|c|}
\hline \multicolumn{3}{|c|}{ Number of Fuel Assemblies } \\
\hline MOX $(2 \%)^{*}$ & $\mathrm{UO}_{2}(3.40 \%)^{*}$ & $\mathrm{UO}_{2}(4.45 \%)^{*}$ \\
\hline 53 & 52 & 52 \\
\hline *in parenthesis is enrichment & & \\
\hline
\end{tabular}


Referring to the data from Table 1 and 2, the calculated atomic density of $\mathrm{UO}_{2}$ and MOX fuel are shown in Table 3 and 4.

TABLE 3: Atomic Density of MOX with 2\% enrichment[13-15].

\begin{tabular}{|c|c|c|}
\hline No. & Nuclide & Atomic density $\left(10^{24}\right.$ atom $\left./ \mathrm{cm}^{3}\right)$ \\
\hline 1. & $\mathrm{U}-235$ & $3.8879 \mathrm{e}-5$ \\
\hline 2. & $\mathrm{U}-235$ & $1.9159 \mathrm{e}-2$ \\
\hline 3. & $\mathrm{Pu}-238$ & $8.3986 \mathrm{e}-5$ \\
\hline 4. & $\mathrm{Pu}-239$ & $2.1706 \mathrm{e}-3$ \\
\hline 5. & $\mathrm{Pu}-240$ & $9.9154 \mathrm{e}-4$ \\
\hline 6. & $\mathrm{Pu}-241$ & $3.6732 \mathrm{e}-4$ \\
\hline 7. & $\mathrm{Pu}-242$ & $2.5174 \mathrm{e}-4$ \\
\hline 8. & $\mathrm{Am}-241$ & $1.0664 \mathrm{e}-4$ \\
\hline 9. & $0-16$ & $4.6330 \mathrm{e}-2$ \\
\hline
\end{tabular}

TABLE 4: Atomic Density of UO fuel with various enrichment.

\begin{tabular}{|c|c|c|c|c|}
\hline \multirow{2}{*}{} & \multirow{2}{*}{ Nuclide } & \multicolumn{3}{|c|}{ Atomic Density $\left(10^{24} \mathrm{atom} / \mathrm{cm}^{3}\right)$, enrich. (\%) } \\
\cline { 2 - 5 } & $2.35 \%$ & $3.4 \%$ & $4.45 \%$ \\
\hline 1. & $\mathrm{U}-235$ & $1.02668 \mathrm{e}-3$ & $1.92585 \mathrm{e}-3$ & $1.00572 \mathrm{e}-3$ \\
\hline 2. & $\mathrm{U}-238$ & $2.23265 \mathrm{e}-2$ & $2.12877 \mathrm{e}-2$ & $1.111691 \mathrm{e}-2$ \\
\hline 3. & $0-16$ & $4.67064 \mathrm{e}-2$ & $4.64272 \mathrm{e}-2$ & $2.42453 \mathrm{e}-2$ \\
\hline
\end{tabular}

\section{Core calculation}

The calculation of Doppler reactivity coefficient using MCNPX is performed step by step as follow:

1. Generation of continuous nuclear data cross section taken from ENDF/B-VII file as a function of temperature ( $300 \mathrm{~K}, 400 \mathrm{~K}, 500 \mathrm{~K}, 600 \mathrm{~K}, 700 \mathrm{~K}, 800 \mathrm{~K}, 900 \mathrm{~K}$ and $1000 \mathrm{~K}$ ) using NJOY99 code.

2. Calculation of fuel atomic density on for $\mathrm{UO}_{2}$ fuel with $3.40 \%$ and $5.45 \%$ enrichment and MOX fuel with $2 \%$ enrichment using the ENDF/B-VII nuclear data generated on step 1.

3. All calculation on step 1 and 2 are performed with temperature of $300 \mathrm{~K}, 400 \mathrm{~K}, 500 \mathrm{~K}, 600$ $\mathrm{K}, 700 \mathrm{~K}, 800 \mathrm{~K}, 900 \mathrm{~K}$ and $1000 \mathrm{~K}$ respectively

4. Calculation of $k_{\text {eff }}$

5. Calculation of Doppler reactivity coefficient.

The Doppler reactivity coefficient is expressed as amount of reactivity change for a parameter change in the reactor, and defined in the following equation (1) [16]:

$$
\alpha_{T}=\frac{\left(k_{e f f[n]}-k_{e f f_{[n-1]}}\right)}{\left(k_{e f f[n]} \times k_{e f f_{[n-1]}}\right)} \times 100 \%
$$

\footnotetext{
$\alpha_{T} \quad$ : Doppler reactivity coefficient

$\mathrm{k}_{\text {eff }[n]} \quad: \mathrm{k}_{\text {eff }}$ on $T$ temperature

$\mathrm{k}_{\text {eff[n-1] }}: \mathrm{k}_{\text {eff }}$ on preceding $T$ temperature
} 


\section{Result and Discussion}

The core reactivity can be direct calculated after determining $k_{\text {eff }}$. The $k_{\text {eff }}$ is calculated on the $\mathrm{UO}_{2}$ and MOX core as a function of temperature respectively. The fuel temperature as the basis of calculation starts from $300 \mathrm{~K}$ up to $1000 \mathrm{~K}$, with $100 \mathrm{~K}$ variation. The resulted $\mathrm{k}_{\text {eff }}$ calculation for $\mathrm{UO}_{2}$ and MOX core are shown in Table 5 and depicted in Figure 3.

TABLE 5: $\mathrm{k}_{\text {eff }}$ calculation for $\mathrm{UO}_{2}$ and MOX fuel.

\begin{tabular}{|c|c|c|c|}
\hline \multirow{2}{*}{ No } & Temperature $(K)$ & \multicolumn{2}{|c|}{$\mathrm{k}_{\text {eff }}$} \\
\hline 1 & 300 & $1.41547 \pm 0.00751$ & $\mathrm{UOX}$ \\
\hline 2 & 400 & $1.41206 \pm 0.00643$ & $1.28357 \pm 0.00621$ \\
\hline 3 & 500 & $1.40067 \pm 0.00828$ & $1.28314 \pm 0.00829$ \\
\hline 4 & 600 & $1.37780 \pm 0.00737$ & $1.27857 \pm 0.00702$ \\
\hline 5 & 700 & $1.37466 \pm 0.00712$ & $1.26254 \pm 0.00795$ \\
\hline 6 & 800 & $1.37286 \pm 0.00743$ & $1.26135 \pm 0.00764$ \\
\hline 7 & 900 & $1.37168 \pm 0.00690$ & $1.26074 \pm 0.00692$ \\
\hline 8 & 1000 & $1.37021 \pm 0.00601$ & $1.25443 \pm 0.00802$ \\
\hline
\end{tabular}

From Figure 4, the $\mathrm{k}_{\text {eff }}$ will decrease as the fuel temperature increases for the $\mathrm{UO}_{2}$ and $\mathrm{MOX}$ core. In general, the $\mathrm{k}_{\text {eff }}$ of MOX core is lower than $\mathrm{UO}_{2}$ core for all temperature. The results of this calculation are in good agreement with the other calculation, showing that the presence of MOX in the core will lower the $k_{\text {eff }}$ [14]. The decrease of $k_{\text {eff }}$ for MOX core is mainly caused by the effect of Pu-239 and Pu-241 having higher neutron absorption macroscopic (1011.3 and 1377 barn) compared to U-235 (680 barn) $[2,18]$.

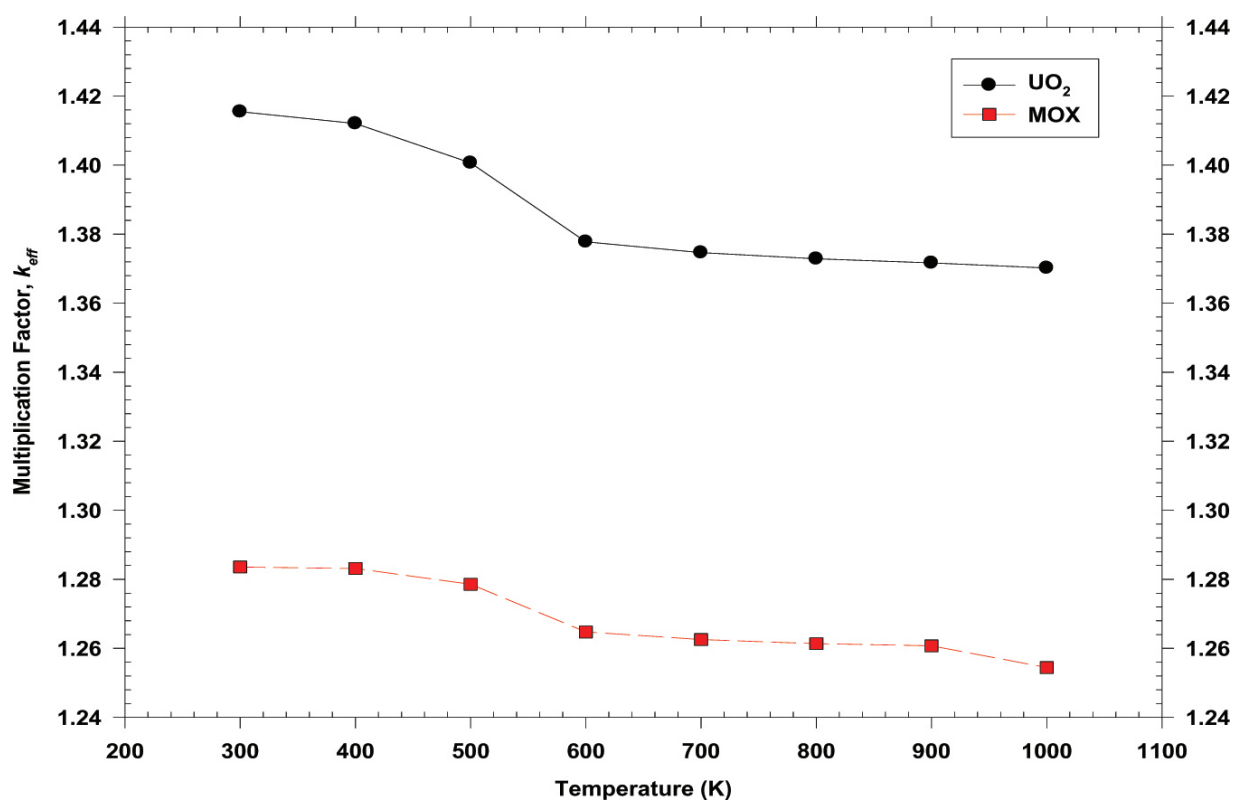

Figure 4: Relation between fuel temperature and keff in the the $\mathrm{UO}_{2}$ and MOX core. 
The effect of fuel temperature increase to decrease the $k_{\text {eff }}$ is also caused by the increase of resonance absorption and fission capture. By referring the $k_{\text {eff }}$ values in Table 5 , the Doppler reactivity coefficient $\left(\alpha_{T}\right)$ can be determined using equation (1) as shown in Table 6 and depicted in Figure 5.

TABLE 6: Doppler reactivity coefficient $\alpha_{T}$ for $\mathrm{UO}_{2}$ and MOX fuel.

\begin{tabular}{|c|c|c|c|}
\hline \multirow{2}{*}{ No } & Temperature (K) & \multicolumn{2}{|c|}{$\alpha_{T}(\mathrm{pcm} / \mathrm{K}) \times 10^{-2}$} \\
\cline { 2 - 4 } & & $\mathrm{UO}_{2}$ & $\mathrm{MOX}$ \\
\hline 1 & $300-400$ & -1.71 & -0.26 \\
\hline 2 & $400-500$ & -5.76 & -2.79 \\
\hline 3 & $500-600$ & -11.90 & -8.56 \\
\hline 4 & $600-700$ & -1.66 & -1.37 \\
\hline 5 & $700-800$ & -0.95 & -0.75 \\
\hline 6 & $800-900$ & -0.63 & -0.38 \\
\hline 7 & $900-1000$ & -0.78 & -3.99 \\
\hline
\end{tabular}

Looking at Figure 5, the Doppler reactivity coefficient of the MOX and $\mathrm{UO}_{2}$ core show a same characteristic as it decreases at temperature of $300 \mathrm{~K}-400 \mathrm{~K}$, then increases at temperatures up to $700 \mathrm{~K}$, and drops again at $1000 \mathrm{~K}$ temperature. In overall, the Doppler reactivity coefficient of $\mathrm{UO}_{2}$ fuels is smaller than the Doppler reactivity coefficient of MOX fuels. This phenomenon is again influenced by the presence of plutonium having a larger absorption cross section (Pu$239=1029$ barn, $\mathrm{Pu}-241=1377$ barn) than of uranium (U-235=681 barn, $\mathrm{U}-238=2.70$ barn) [19].

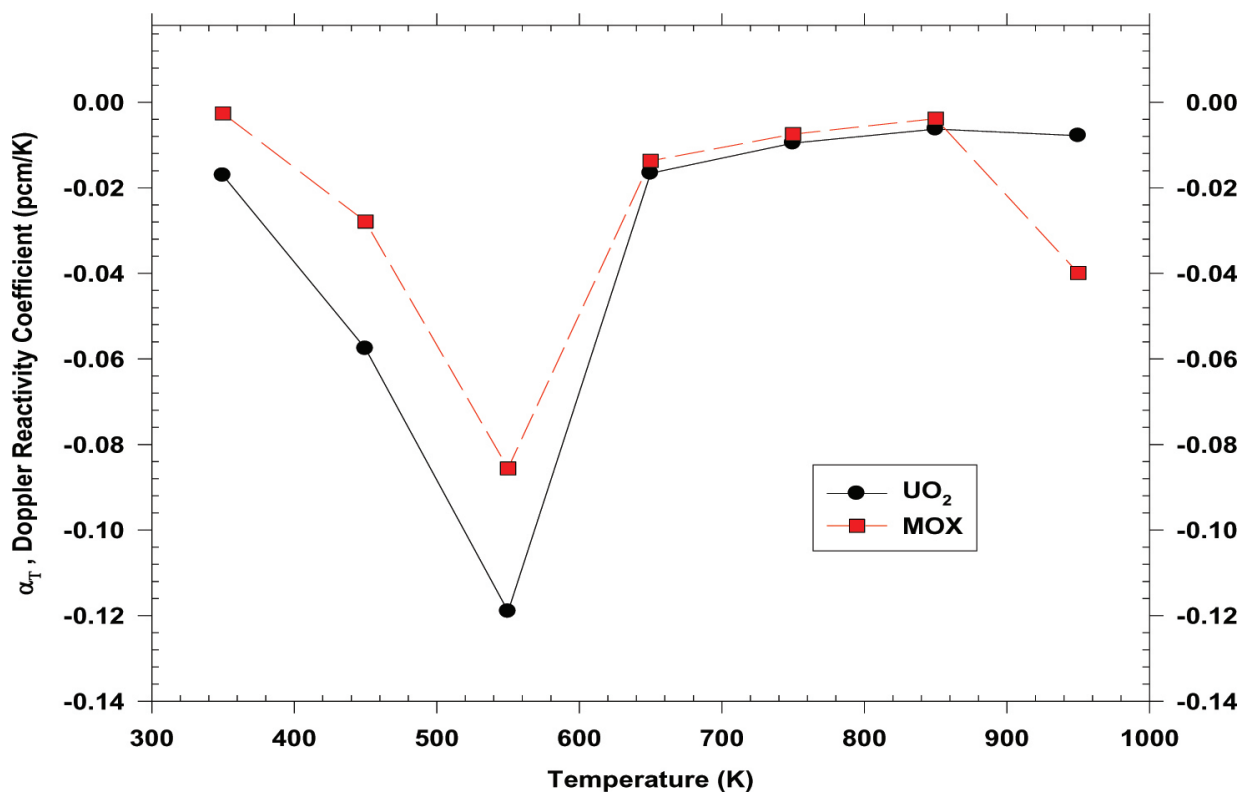

Figure 5: Relation between fuel temperature and Doppler reactivity coeficient in the the $\mathrm{UO}_{2}$ and $\mathrm{MOX}$ core.

\section{Conclusions}

The Doppler reactivity coefficient with MOX fuel in the typical PWR-1000 reactor core has been calculated using the Monte Carlo MCNPX transport program. The results show that the Doppler reactivity coefficient decreased to a critical value as the fuel temperature increased. This is 
because the presence of Pu-239 and Pu-24. Since the absorption cross section of MOX fuel is much bigger than the absorption cross section of uranium, the Doppler reactivity coefficent become negative, so that the core of typical PWR-1000 reactor core with MOX fuel is considered to be safe to be operated.

\section{Acknowledgment}

The authors would like to express many thanks to Division Head of Physics and Reactor Technology (BFTR) for valuable support to the writing of this paper. Moral supports from colleagues on BFTR-PTKRN are greatly appreciated.

\section{References}

[1] SEMBIRING, TM, Analisis Pengaruh Bahan Bakar MOX Terhadap Parameter Teras Reaktor Benchmark. , J. Teknologi Reaktor Nuklir, Vol 9 No.1, Februari 2007.

[2] MASSIH, Ali R, Model for MOX Fuel Behaviour, SKI repot 2006:10, January 2006.

[3] STAICU, D and BARKER, M, Thermal Conductivity of Heterogeneous LWR MOX Fuels", Journal of Nuclear Materials 442 (2013) 46-52

[4] STAICU, D, Thermal Conductivity of Homogeneous and Heterogeneous MOX Fuel with up to $44 \mathrm{MWd} / \mathrm{kgHM}$ Burn-up, Journal of Nuclear Materials 412 (2011) 129-137

[5] AMAYA Masaki, NAKAMURA Jinichi, NAGASE Fumihisa, FUKETA Toyoshi, Thermal Conductivity Evaluation of High Burnup Mixed-Oxide (MOX) Fuel Pellet, Journal of Nuclear Materials 414 (2011) 303-308

[6] TATSUMI, M, Analysis of High Moderator PWR MOX Core MISTRAL-4 with SRAC and MVP, Jurnal of Nuclear Science and Technology, Supplement 2, p 864-867, August 2002.

[7] SEUBERT, A, et al, Solution of the Stationary State of the PWR MOX/UO Core Transient Benchmark, PHISOR 2006, ANS Topical Meeting on Reactor Physics, Canadian Nuclear Society, Vencouver, September 10-14, 2006.

[8] RIVEROLA, J, RIA Analysis for PWR at both HZP and HFP Operation and all Cycle Fuel Exposure with 3D Techniques", Proceeding of the 2004 International meeting on LWR Fuel Performance, Oriando, Florida, September 19-22, 2004

[9] HENDRICKS, J. S., MCKINNEY, G. W., et al., MCNPX 2.6.0 Extensions, LA-UR-08-2216", LoS Alamos National Laboratory, 11 April 2008

[10] CHADWICK, M. B., OBLOZINSKY, P., HERMAN, M., et al., ENDF/B-VII: Next Generation Evaluated Nuclear Data Library for Nuclear Science and Technology, Nuclear Data Sheets, Vol. 107, pp. 2931-3060, 2006

[11] ROKHMADI dan SEMBIRING, TM, Verifikasi Perhitungan Reaktivitas Batang Kendali Teras Reaktor PWR AP1000, Prosiding Seminar Nasional Pengembangan Energi Nuklir VI, Jakarta, 11 Juni 2013.

[12] Westinghouse AP100o Control Document Rev.16 [internet]. US: Westinghouse;2007. Tier 2 Chapter 4 Reactor, [cited 2010 August 3]. Available from: http://adamswebsearch2.nrc. gov/idmws/ViewDocByAccession.asp?AccessionNumber=ML071580939

[13] YAMAMOTO, A, et al, Benchmark Problem Suite for Reactor Physics Study of LWR Next Generation Fuels, Journal of Nuclear Science and Technology Vol 39 No.8 p.900-912 (August 2002). 
[14] MOUSTAFA Aziz and MASSOUD Eman, Burn-up Analysis for a PWR Fuel Pin of the Next Generation, Arab Journal of Nuclear Science and Applications, 47(3), (93-103) 2014

[15] KLOOSTERMAN, Program MOX A Tool for the Calculation of Nuclide Densities in MOX Fuels, NFA-ACT-95-09, December 1995

[16] ROKHMADI, Analisis Faktor Multiplikasi Tak Hingga Bahan Bakar PWR Akibat Perubahan, Temperatur dan Data Nuklir, Prosiding Seminar Nasional Teknologi dan Keselamatan PLTN serta Fasilitas Nuklir ke13, UIN-BATAN, Jakarta 6 Nopember 2007

[17] ROKHMADI, Analisis Reaktivitas Batang Kendali pada Desain Teras MOX PWR AP1000, Prosiding Seminar Nasional Teknologi dan Keselamatan PLTN serta Fasilitas Nuklir ke 19, Yogyakarta, 24-25 September 2013.

[18] TUKIRAN, Menentukan Parameter Kinetik Reaktor PWR AP 600, Prosiding Laporan Tahunan P2TRR Tahun 2004.

[19] TUKIRAN, Evaluasi Parameter Kinetik Terhadap Keselamatan Teras AP100o Berbahan Bakar MOX, Prosiding Seminar Nasional Teknologi dan Keselamatan PLTN serta Fasilitas Nuklir ke 19, Yogyakarta, 24-25 September 2013. 